\title{
List of Works
}

Published under the Auspices of the

\section{School of Oriental \\ and African Studies}

1946-1991 
[The works included in this list have been published either entirely at the expense of the School or with substantial assistance from the School's publications fund. All prices shown are subject to alteration without notice. Orders should be placed through normal trade channels.

The list does not include the many works by members of the academic staff of the School published without assistance from the publications fund.]

Published by SchOOL of ORIENTAL AND African STUdies. (Orders should be sent to the Publications Officer, School of Oriental and African Studies, Thornhaugh Street, Russell Square, London WC1H 0XG.)

*An asterisk indicates that the book has been transferred from the original publisher, and is now distributed by the School.

Collected Papers in Oriental and African Studies

$£ \quad p$.

1. M. Guthrie (ed.): African Language Studies I (1960) . . $\quad 1000$

2. M. Guthrie (ed.): African Language Studies II (1961) . $\quad$. $10 \quad 00$

3. M. Guthrie (ed.): African Language Studies III (1962) . $\quad . \quad 10 \quad 00$

4. H. L. Shorto (ed.): Linguistic Comparison in South East Asia and the Pacific (1963)

5. M Guthrie (ed ): African Language Studies IV (1963) . 800

5. M. Guthrie (ed.). African Language Studies IV (1963) • $\cdot 1000$

6. M. Guthrie (ed.): African Language Studies V (1964) . . 1000

7. M. Guthrie (ed.): African Language Studies VI (1965) . . 1000

8. M. Guthrie (ed.): African Language Studies VII (1966) . $\quad . \quad 1000$

I. Richardson and W. M. Mann: A vocabulary of Sụkụma (African Language Studies VII Offprint) (1967) . $\quad . \quad 4 \quad 400$

A. V. King: A. Bòoríi Liturgy from Katsina (African Language Studies VII Supplement) (1967) . $\quad . \quad 500$

9. M. Guthrie (ed.): African Language Studies VIII (1967) $\quad . \quad 10 \quad 00$

10. M. Guthrie (ed.): African Language Studies IX (1968) . $\quad . \quad 10 \quad 00$

11. M. Guthrie (ed.): African Language Studies X (1969) . . $10 \quad 00$

12. W. G. Atkins (ed.).: African Language Studies XI (1970) . $12 \quad 00$

13. W. H. Whiteley (ed.): African Language Studies XII (1971) . $10 \quad 00$

14. W. H. Whiteley (ed.): African Language Studies XIII (1972) . $10 \quad 00$

15. D. W. Arnott (ed.): African Language Studies XIV (1973) . $10 \quad 00$

16. D. W. Arnott (ed.): African Language Studies XV (1974) $\quad . \quad 10 \quad 00$

17. D. W. Arnott (ed.): African Language Studies XVI (1975) . $10 \quad 00$

18. G. Innes (ed.): African Language Studies XVII (1980) . . 1000

INAUGURAL LECTURES

A. N. Allott: Law and Language (1965)

J. N. D. Anderson: The Relevance of Oriental and African Legal Studies (1954)

A. L. Basham: The Indian Sub-Continent in Historical Perspective (1958)

C. E. Bazell: Linguistic Typology (1958)

W. G. Beasley: The Basis of Japanese Foreign Policy in the Nineteenth Century (1955) .

o.p.

o.p.

o.p.

o.p.

C. F. Beckingham: The Achievements of Prester John (1966)

J. Berry: Spoken Art in West Africa (1961)

o.p.

o.p.

C. D. Cowan: South East Asian History in London (1963) . . o.p. 
F. J. Daniels: Japanese Studies in the University of London and Elsewhere (1963)

J. D. M. Derrett: An Oriental Lawyer looks at the Trial of Jesus and the Doctrine of the Redemption (1966)

C. A. Fisher: The Reality of Place (1965)

C. J. Gadd: Teachers and Students in the Oldest Schools (1956)

A. Gledhill: Whither Indian Law? (1956)

S. H. Hansford: The Study of Chinese Antiquities (1956)

E. J. A. Henderson: The Domain of Phonetics (1965)

P. M. Holt: The Study of Modern Arab History (1965)

A. K. S. Lambton: Islamic Society in Persia (1954)

D. M. Lang: Landmarks in Georgian Literature (1966)

R. A. Oliver: African History for the Outside World (1964)

E. T. Penrose: Economics and the Aspirations of le tiers Monde (1965)

R. H. Robins: General Linguistics within a Liberal Education (1966)

N. C. Scott: The Place of Phonetics in the University (1961)

J. B. Segal: Edessa and Harran (1963)

R. B. Serjeant: The Saiyids of Hadramawt (1957)

Hugh Tinker: The City in the Asian Polity (1964)

D. C. Twitchett: Land Tenure and the Social Order in T'ang and Sung China (1962)

E. Ullendorff: The Challenge of Amharic (1965) .

W. Watson: Inner Asia and China in the Pre-Ham Period (1969)

D. J. Wiseman: The Expansion of Assyrian Studies (1962) .

J. C. Wright: Non-Classical Sanskrit Literature (1966)

o.p.

o.p.

200

200

o.p.

200

200

o.p.

o.p.

o.p.

200

200

200

200

o.p.

200

o.p.

o.p.

o.p.

o.p.

o.p.

\section{Foundation DAY LECTURES}

H. W. Butterfield: History and Man's Attitude to the Past (1961)

Sir Eric Ashby: Patterns of Universities in Non-European Societies (1961) .

Sir Hamilton Gibb: Area Studies Reconsidered (1963)

Sir Keith Hancock: Smuts and the Shift of World Power (1964).

Sir Willis Jackson: Technology and the Developing Countries (1966)

Philip Mason: Race Relations: A Field of Study comes of Age (1968)

O. Lattimore: Britain's Opportunity in Asian Studies (1970)

A. T. Hatto: Shamanism and Epic Poetry in Northern Asia (1970)

Lord Fulton: The Expanding World of the Universities (1972) .

The Gandhi Memorial Lecture

Krishna Kripalani: Gandhi, the Modern Mahatma (1970) . 
Fascicle III (1955)

Fascicle IV (1963)

Fascicle V (1969)

Fascicle VI (1981)

The set of six

\section{OTHER WORKS}

B. W. Andrzejewski: The Declensions of Somali Nouns (1964)

E. Balazs: Political Theory and Administrative Reality in Traditional China (1965)

J. Brough: Selections from Classical Sanskrit Literature (Second edition 1978)

J. H. Carter: Syntax and Tone in Kongo (1973)

o.p.

o.p.

$\begin{array}{ll}4 & 00\end{array}$

600

J. H. Carter and G. P. Kahari: Kuverenga ChiShóna (Second edition 1987), 2 parts .

600

M. Chitakasem and A. G. W. Turton (ed.): Thai Constructions of Knowledge (1991)

$10 \quad 00$ o.p.

T. W. Clark: Introduction to Nepali (Second edition 1977) .
J. H. C. S. Davidson (ed.): Austroasiatic Languages: essays in honour of H. L. Shorto (1991)

J. H. C. S. Davidson (ed.): Laī Sū' Thai: essays in honour of Professor E. H. S. Simmonds (1987)

J. H. C. S. Davidson (ed.): Pacific Island Languages: essays in honour of G. B. Milner (1990)

J. H. C. S. Davidson (ed.): South-East Asian Linguistics: essays in honour of Eugénie J. S. Henderson (1989) .

J. H. C. S. Davidson and H. Cordell (ed.): The Short Story in South East Asia: aspects of a genre (1982) .

1400

600

1200

900

700

A. Gacek: Catalogue of the Arabic Manuscripts in the Library of the School of Oriental and African Studies, University of London (1981)

L. H. Glinert: Chik-Chak! - a gateway to modern Hebrew grammar (1991) .

A. C. Graham: Later Mohist Logic, Ethics and Science [Published in Hong Kong by the Chinese University Press] (1978)

A. C. Graham: Chuang-tzú: textual notes to a partial translation (1982)

M. Guthrie: Bantu Sentence Structure (1961)

A. A. Haidari: Modern Persian Reader (1975)

R. A. Hamilton (ed.): History and Archaeology in Africa-First Conference (1955)

R. J. Hayward (ed.): Omotic Language Studies (1990)

R. Hedinger: The Manenguba Languages (Bantu A.15, Mbo cluster) of Cameroon (1987)

M. Hiskett: A. History of Hausa Islamic Verse (1975)

P. J. Honey (trans. and ed.): P. J. B. Truong-vĩnh-Ký: Voyage to Tonking in the Year Ât-họi (1876) (1982)

E. Hook: A Guide to the Papers of John Swire and Sons Ltd. (1977)

M. J. Hutt: Nepali-a National Language and its Literature (1988).

G. Innes: The Structure of Sentences in Mende (1963)

G. Innes: An Introduction to Grebo (1966)

o.p.

600

1600

$o . p$.

o.p.

$7 \quad 00$ 
G. Innes: A Practical Introduction to Mende (1967) . $\quad$. $\quad \begin{array}{lll}\quad & 8 & 00\end{array}$

G. Innes: Sunjata-Three Mandinka Versions (1974) . $\quad \begin{array}{rl}0 & 00\end{array}$

G. Innes: Kaabu and Fuladu: Historical Narratives of the Gambian Mandinka (1976)

G. Innes: Kelefa Saane-His Career Recounted by Two Mandinka Bards (1978) . . . . . . .

T. M. Johnstone: Mehri Lexicon and English-Mehri Word-list (1987)

D. H. Jones (ed.): History and Archaeology in Africa-Second Conference (1959)

1100

900

$20 \quad 00$

300

$4 \quad 00$

H. Kabir: Rabindranath Tagore (1962)

E. U. Kratz: Bibliography of Indonesian Literature in Journals (1989).

B. Lewis (ed.): The Fall of Constantinople (1955)

$30 \quad 00$

o.p.

o.p.

G. H. Luce: A Comparative Word-List of Old Burmese, Chinese and Tibetan (1981)

D. N. MacKenzie: The Khwarezmian Element in the Qunyat al-munya (1990) .

D. J. Matthews: A Course in Nepali (1984) . . .

Joan Maw: Sentences in Swahili (1969) . $\quad . \quad$. $\quad . \quad$.

Joan Maw: Swahili Style-a Study (1974) . . . . . .

Joan Maw and John Kelly: Intonation in Swahili (1975) . .

J. H. McGlynn and E. U. Kratz (ed): Walking Westward in the Morning: seven contemporary Indonesian poets (1990)

G. B. Milner (ed.): Natural Symbols in South East Asia (1978) .

M. Mindlin, M. J. Geller and J. E. Wansbrough (ed.): Figurative Language in the Ancient Near East (1987) .

D. O. Morgan (ed.): Medieval Historical Writing in the Christian and Islamic Worlds (1982)

T. Mukherjee: A Catalogue of the Bengali Manuscripts of the Vrindaban Research Institute (1978).

600

$5 \quad 00$

W. D. O'Flaherty and J. D. M. Derrett (ed.): The Concept of Duty in South Asia [Published in India by Vikas Publishing House Pvt. Ltd.] (1978)

P. G. O'Neill: A Programmed Introduction to Literary-Style Japanese (1968)

J. W. A. Okell: First Steps in Burmese (with 5 cassettes) (1989) .

R. Pankhurst (ed.): Tax Records and Inventories of Emperor Téwodros of Ethiopia (1855-1868) (1978)

E. M. Parker and R. J. Hayward: An Afar-English-French Dictionary (1985)

C. H. Philips and M. D. Wainwright (ed.): Indian Society and the Beginnings of Modernisation c. 1830-1850 (1976) .

Johan Pottier (ed.): Food Systems in Central and Southern Africa (1986)

I. M. P. Raeside: Gadyaraja, a fourteenth century version of the Kṛ̦na legend (1989)

I. M. P. Raeside: Marathi Reading Course (1991)

C. H. B. Reynolds: Sinhalese, an Introductory Course (1980)

I. Richardson: The Role of Tone in Sukưma (1959)

M. C. Ricklefs: Modern Javanese Historical Tradition: a study of an orginial Kartasura chronicle and related materials (1978) 
E. C. Rowlands: A Grammar of Gambian Mandinka (1959)

N. C. Scott: A Dictionary of Sea Dayak (1956).

$10 \quad 00$

C. Shackle: The Siraiki Language of Central Pakistan, a o.p. Reference Grammar (1976).

$10 \quad 00$

C. Shackle: A Gurū Nānak Glossary (1981)

1200

C. Shackle: An Introduction to the Sacred Language of the Sikhs (1983)

800

C. Shackle (ed.): Urdu and Muslim South Asia, studies in honour of Ralph Russell (1989)

S. R. Schram (ed.): The Scope of State Power in China (1985)

S. R. Schram (ed.): Foundations and Limits of State Power in China (1987)

W. E. Skillend: Kodae Sosŏl (1969) . . . .

T. Skorupski (ed.): The Buddhist Forum, Volume I (1990).

T. Skorupski (ed.): The Buddhist Forum, Volume II (1991)

N. V. Smith: Outline Grammar of Nupe (1967) .

R. B. Smith and A. J. Stockwell (ed.): British Policy and the Transfer of Power in Asia-Documentary Perspectives (1988)

R. Snell: The Eighty-Four Hymns of Hita Harivamśa: an edition of the Caurāsì Pada (1991) .

P. A. Stott (ed.): Nature and Man in South East Asia (1978)

$10 \quad 00$

2000

2500

1000

600

$10 \quad 00$

500

R. L. Turner: A Comparative Dictionary of the Indo-aryan Languages: Addenda and Corrigenda (1985)

E. Ullendorff: An Amharic Chrestomathy (Second edition 1978)

M. D. Wainwright (ed.): Brothers in India: the correspondence of Tom, Alfred and Christopher Bassano, 1841-75 (1979)

E. O. J. Westphal: Kwangari-an Index of Lexical Types (1959)

W. H. Whiteley: Some Problems of Transitivity in Swahili (1968)

$7 \quad 00$

o.p.

600

M. H. Williams: Catalogue of the Papers of Sir Charles Addis (1986).

W. A. A. Wilson: An Outline of Temne (1962)

1400

o.p.

I. Yamada: Karuṇāpuṇḍarika (1968) .

S.O.A.S.-Library: Cumulated list of Periodical Articles on the Far East and South East Asia, May 1956-April 1957 (1958).

S.O.A.S.-Library: Cumulated List of Periodical Articles on the Far East and South East Asia, May 1957-April 1958 (1959)

$16 \quad 00$

o.p.

o.p.

SOAS South Asian TeXTs

1. C. Shackle and R. Snell: Hindi and Urdu since 1800: a common reader (1990)

2. R. Snell: The Hindi Classical Tradition, a Braj Bhāṣā Reader (1991).

OcCasional Papers In ThIRd-World Economic History

1. G. Balachandran: India in Britain's Liquidity Crisis: the stabilization of 1920 (1990).

2. P. Francks, J. Hunter and K. Sugihara: Japanese Economic History in Britain: Some Lessons from Teaching Experience (1991).

3. P. Kingston, R. G. Tiedemann and N. Westcott: Managed Economies in World War II (1991) 
JoRdan Lectures in Comparative Religion

[For Volumes 1-12 see The Athlone Press]

13. D. Seyfort Ruegg: Buddha-nature, Mind and the Problem of Gradualism in a Comparative Perspective, on the transmission and reception of Buddhism in India and Tibet (1989)

14. Jonathan Z. Smith: Drudgery Divine, on the comparison of early Christianities and the religions of Late Antiquity (1990)

Published by the School of ORIENTAL AND African Studies for the Corpus INSCRIPTIONUM IRANICARUM

M. Shokoohy: Haryana I-The Column of Fìrūz Shāh and other Islamic Inscriptions from the District of Hisar (1988) .

N. Sims-Williams: Sogdian and other Iranian Inscriptions of the Upper Indus I (1989)

$60 \quad 00$

$50 \quad 00$

N. Sims-Williams and J. Hamilton: Documents turco-sogdiens du IXe-Xe siècle de Touen-houang (1990) .

W. Sundermann: The Manichaean Hymn Cycles Huyadagmān and Angad Röšnān in Parthian and Sogdian (1990)

R. Schmitt: The Bisitun Inscriptions of Darius the Great-Old Persian Text (1991)

Published by OXFord UnIVERSITY Press

LONDON ORIENTAL SERIES

*1. W. S. Allen: Phonetics in Ancient India (1953)

2. J. B. Segal: The Diacritical Point and the Accents in Syriac (1953)

*3. Mary Boyce: The Manichaean Hymn Cycles in Parthian (1954)

900

o.p.

900

4. E. G. Pulleyblank: The Background of the Rebellion of An LuShan (1955)

5. K. Ballhatchet: Social Policy and Social Change in Western India, 1817-1830 (1957)

6. D. L. Snellgrove: The Hevajra Tantra (1959)

*7. J. Brough: The Gāndhārī Dharmapada (1962)

8. C. J. Dowsett: The History of the Caucasian Albanians by Movsēs Dasxurançi (1961) .

*9. D. N. MacKenzie: Kurdish Dialect Studies I (1961)

*10. D. N. MacKenzie: Kurdish Dialect Studies II (1962)

11. C. D. Cowan: Nineteenth-Century Malaya-the Origins of British Political Control (1961) .

12. J. B. Segal: The Hebrew Passover from the Earliest Times to A.D. 70 (1963)

*13. F. R. Palmer: The Morphology of the Tigre Noun (1962)

14. R. Williams: Jaina Yoga (1963) [Reprinted by Motilal Banarsidass, 1983]

*15. E. J. A. Henderson: Tiddim Chin: a Descriptive Analysis of Two Texts (1965)

16. V. L. Ménage: Neshri's History of the Ottomans: the Sources and Development of the Text (1965)

*17. T. M. Johnstone: Eastern Arabian Dialect Studies (1967)

18. D. L. Snellgrove: The Nine Ways of Bon (1967)

*19. R. E. Emmerick: Tibetan Texts concerning Khotan (1967) 
*20. R. E. Emmerick: Saka Grammatical Studies (1968) . . 1600

*21. R. E. Emmerick: The Book of Zambasta (1968) . . . 1800

*22. D. N. MacKenzie: The "Sūtra of the Causes and Effects of Actions" in Sogdian (1970)

*23. R. E. Emmerick: The Khotanese Śūrangamasamādhisūtra (1970)

*24. H. L. Shorto: A Dictionary of the Mon Inscriptions from the Sixth to the Sixteenth Centuries (1971)

900

1000

2200

*25. H. Rabie: The Financial System of Egypt, A.H. 564-741/ A.D. 1169-1341 (1972)

26. S. G. Karmay: The Treasury of Good Sayings: A Tibetan History of Bon (1972)

*27. M. A. Cook: Population Pressure in Rural Anatolia, 14501600 (1972)

28. O. Wright: The Modal System of Arab and Persian Music A.D. $1250-1300$ (1978)

*29. P. M. Thompson: The Shen Tzu Fragments (1979) . .

*30. M. C. Ricklefs: Jogjakarta under Sultan Mangkubumi 17491792: a History of the Division of Java (1974)

31. J. Wansbrough: Quranic Studies: Sources and Methods of Scriptural Interpretation (1977) .

*32. P. G. Robb: The Government of India and Reform, Policies Towards Politics and the Constitution 1916-1921 (1976) .

*33. A. T. Hatto: The Memorial Feast for Kökötöy-khan: a Kirghiz Epic Poem (1977) .

*34. J. Wansbrough: The Secrarian Milieu: Content and Composition of Islamic Salvation History (1978)

*35. P. Ch'en: The Formation of the Early Meiji Legal Order: the Japanese Code of 1871 and its Chinese Foundation (1981)

900

o.p.

900

o.p.

36. A. K. S. Lambton: State and Government in Medieval Islam: an Introduction to the Study of Islamic Political Theory: the Jurists (1981)

37. S. Hopkins: Studies in the Grammar of Early Arabic (1984).

38. G. Khan: Studies in Semitic Syntax (1988)

\section{LONDON ORIENTAL BIBLIOGRAPHIES}

1. H. R. Klieneberger: Bibliography of Oceanic Linguistics (1957)

*2. H. L. Shorto, J. M. Jacob and E. H. S. Simmonds: Bibliography of Mon-Khmer and Tai Linguistics (1963)

*3. W. R. Roff: Bibliography of Malay and Arabic Periodicals 1876-1941 (1972)

4. D. G. Chibbett, B. F. Hickman and S. Matsudaira: A Descriptive Catalogue of the pre-1868 Japanese Books, Manuscripts and Prints in the Library of the School of Oriental and African Studies (1975)

*5. M. C. Ricklefs and P. Voorhoeve: Indonesian Manuscripts in Great Britain, a Catalogue of Manuscripts in Indonesian Languages in British Public Collections (1977) .

$$
\text { o.p. }
$$

Historical Writing on the Peoples of Asia

1. C. H. Philips (ed.): Historians of India, Pakistan and Ceylon (196I)

2. D. G. E. Hall (ed.): Historians of South East Asia (1961) 
3. W. G. Beasley and E. G. Pulleyblank (ed.): Historians of China and Japan (1961)

4. Bernard Lewis and P. M. Holt (ed.): Historians of the Middle East (1962)

o.p.

o.p.

Annotated African Texts (distributed by Luzac and Co. Ltd.)

1. W. G. Atkins (ed.): Unkhoswe waaNyanja (1952) .

o.p.

2. W. G. Atkins (ed.): Ukawamba (1953)

3. A. N. Tucker (ed.): Inkuti Pukunot oo IMaasai (1954)

o.p.

200

4. B. W. Andrzejewski (ed.): Hikmad Soomaali (1956) . . 400

5. J. H. Carter (ed.): Soko Risina Musoro (1958)

300

OTHER WORKS

${ }^{*}$ B. W. Andrzejewski: Leopard Among the Women (Shabeelnagood): a Somali Play by Hassan Sheikh Mumin (1974)

o.p.

*W. G. Beasley: Select Documents on Japanese Foreign Policy, 1853-1868 (1955)

*L. Caplan: Administration and Politics in a Nepalese Town: The Study of a District Capital and its Environs (1975)

900

M. A. Cook (ed.): Studies in the Economic History of the Middle East (1970)

J. R. Firth: Papers in Linguistics, 1934-1951 (1957)

A. Guillaume: The Life of Muhammad (1955)

M. Guthrie: Bantu Word Division (1948)

[Published for the International African Institute]

*D. G. E. Hall: Henry Burney-a Political Biography (1974)
*P. M. Holt (ed.): Political and Social Change in Modern Egypt (1968)

J. M. Jacob: Introduction to Cambodian (1968)

$25 \quad 00$

o.p.

o.p.

o.p.

900

$10 \quad 00$

2500

J. M. Jacob: A Concise Cambodian-English Dictionary (1974) . $\quad 3000$

*T. M. Johnstone: Harsūsi Lexicon (1977) . . . . . . 2000

T. M. Johnstone: Jibbāli Lexicon (1982) . . . . . . . 3500

A. M. Jones: Studies in African Music (1959) . . . . . o.p.

J. M. B. Jones: The Kitäb al-Maghāzī of al-Wāqidi (1967) . . o.p.

D. J. Kamhi: Modern Hebrew: an introductory course (1982) . o.p.

H. M. Lambert: Introduction to the Devanagari Script for students of Sanskrit, Hindi, Bengali, Marathi and Gujarati (1953) .

H. M. Lambert: Introduction to the Devanagari Script for students of Sanskrit and Hindi (1953)

H. B. Lee: Korean Grammar (1989)

G. H. Luce: Phases of Pre-Pagán Burma (1985)

Set of two volumes

o.p.

o.p.

$27 \quad 50$

10500

2100

D. N. MacKenzie: A Concise Pahlavi Dictionary (1971)
${ }^{D}$ D. J. Matthews and C. Shackle: An Anthology of Classical Urdu Love Lyrics (1972)

*Noel Matthews and M. D. Wainwright: A Guide to Manuscripts and Documents in the British Isles relating to Africa (1971)

*Noel Matthews and M. D. Wainwright: A Guide to Manuscripts and Documents in the British Isles relating to the Far East (1977)

*Noel Matthews and M. D. Wainwright: A Guide to Western Manuscripts and Documents in the British Isles relating to the Middle East and North Africa (1980) . . . . 
J. E. M. Maw: Twende!--a practical Swahili course (1985)

$£ p$.

$17 \quad 50$

o.p.

200

Hardbound edition

Paperback edition

W. D. O'Flaherty: Asceticism and Eroticism in the Mythology of Siva (1973).

J. W. A. Okell: A Reference Grammar of Colloquial Burmese (1969)

V. J. Parry and M. E. Yapp (ed.): War, Society and Technology in the Middle East (1975)

${ }^{*}$ C. H. Philips (ed.): The Correspondence of Lord William Cavendish Bentinck, Governor-General of India, Volume I 1828-1831, Volume II 1832-1836 (1977) . . The set

${ }^{*}$ H. L. Shorto: A Dictionary of Modern Spoken Mon (1962) .

R. B. Smith and W. Watson (ed.): Early South East Asia (1979)

P. Spencer: Nomads in Alliance (1973)

R. L. Turner: A Comparative Dictionary of the Indo-aryan Languages (1966)

Index Volume (1969)

*Phonetic Analysis of the Headwords (1971)

R. L. Turner: Collected Papers 1912-1973 (1975)

E. Ullendorff (ed.): The Autobiography of Emperor Haile Sellassi

I: 'My Life and Ethiopia's Progress' 1892-1937 (1976)

${ }^{*} E$. Ullendorf and C. F. Beckingham: The Hebrew Letters of Prester John (1982)

*M. D. Wainwright and Noel Matthews: A Guide to Western Manuscripts and Documents in the British Isles relating to South and South East Asia (1965)

N. Waterson: Uzbek-English Dictionary (1980).

$18 \quad 00$

$27 \quad 50$

2500

1400

$30 \quad 00$

o.p.

$60 \quad 00$

3250

1800

o.p.

2250

1400

Published by GeOrge Allen and Unwin, Ltd.

Studies on Modern Asia AND AFriCa

1. C. H. Philips (ed.): Politics and Society in India (1963) .

2. J. N. D. Anderson (ed.): Changing Law in Developing Countries (1963)

3. C. D. Cowan (ed.): The Economic Development of South East Asia (1964)

4. C. D. Cowan (ed.): The Economic Development of China and Japan (1964)

5. S. R. Mehrotra: India and the Commonwealth, 1885-1929 (1965).

6. J. N. D. Anderson (ed.): Family law in Asia and Africa (1968)

7. P. J. Vatikiotis (ed.): Egypt since the Revolution (1968) .

8. D. Hopwood (ed.): The Arabian Peninsula (1972) .

9. P. J. Vatikiotis (ed.): Revolution in the Middle East (1972)

10. G. N. Brown and M. Hiskett (eds.). Conflict and Harmony in Education in Tropical Africa (1975)

11. W. G. Beasley (ed.): Modern Japan: Aspects of History, Literature and Society (1975)

12. C. von Fürer-Haimendorf: The Gonds of Andhra Pradesh (1979) $o . p$.

o.p.

o.p.

o.p.

o.p.

o.p.

$o . p$.

$20 \quad 00$

o.p.

o.p.

o.p. 
OTHER WORKS

R. Russell (ed.: Ghälib: the Poet and his Age (1972) . . . . o.p.

Published by The Athlone Press

JoRdan Bequest LeCTURes in Comparative Religion

1. L. Renou: Religions of Ancient India (1953) . . . . . o.p.

2. D. Daube: The New Testament and Rabbinic Judaism (1956) . o.p.

3. P. Lévy: Buddhism: a "Mystery Religion"? (1957) . . . . o.p.

4. H. H. Rowley: Prophecy and Religion in Ancient China and Israel (1956)

E. O. James: The Worship of the Sky-God (1963) . . . o.p.

7. W. F. Albright: Yahweh and the Gods of Canaan (1968) . o.p.

8. A. K. Cragg: The Privilege of Man (1968) . . . . o.p.

9. J. Gonda: Vișnuism and Śivaism (1970) . . . . . 2300

11. R. J. Zwi Werblowsky: Beyond Tradition and Modernity: $\begin{array}{llll}\text { Changing Religions in a Changing World (1976) } \quad . \quad & 17 \quad 50\end{array}$

12. H. W. F. Saggs: The Encounter with the Divine in Mesopotamia and Israel (1978).

[Further volumes are published by the School]

Published by LuZAC AND Co., LTD.

A. L. Basham: History and Doctrines of the Äjivikas (1951) . o.p.

W. G. Beasley: Great Britain and the Opening of Japan (1951) . o.p.

J. Brough: Selections from Classical Sanskrit Literature (195I) second edition published by S.O.A.S.

C. C. Brown: Studies in Country Malay (1956) .

500

C. J. Dunn: The Early Japanese Puppet Drama (1966) . . 50

P. Hardy: Historians of Medieval India (1960) . . . . . o.p.

[Reprinted by Greenwood Press, Westport, Conn., 1982]

C. Hooykaas: The Lay of Jaya Prana (1958)

500

J. F. P. Hopkins: Medieval Muslim Government in Barbary (1958)

B. Lewis: Handbook of Diplomatic and Political Arabic (1947) .

Hla Pe: Konmara Pya Zat (1952)

J. A. Stewart: A Manual of Colloquial Burmese, Part I (1955) .

A. S. Tritton: Materials on Muslim Education in the Middle Ages (1957)

$o . p$.

o.p.

500

450

o.p.

Published by W. HeFFer AND Sons, LTD.

*J. Berry: The Pronunciation of Ewe (1951)

200

J. Berry: The Pronunciation of Ga (1951)

o.p.

T. W. Clark: Introduction to Nepali (1963).

V. Minorsky: A History of Sharvān and Darband in the 10th-11th Centuries (1958) .

J. D. Pearson: Index Islamicus (1958) [Now published by Mansell]

J. D. Pearson: Index Islamicus-First Supplement (1962) [Now published by Mansell].

Ida C. Ward: An Introduction to the Yoruba Language (1952)

o.p.

3500

o.p.

Published by Lund Humphries AND Co., LTD.

*M. Boyce and I. Gershevitch (ed.): W. B. Henning Memorial Volume (1970) 
F. J. Daniels (ed.): Selections from Japanese Literature (Twelfth to

Nineteenth Centuries) (1959)

A. C. Graham: Two Chinese Philosophers (1958).

Yin C. Liu: Fifty Chinese Stories (1960)

o.p.

o.p.

$5 \quad 95$

P. G. O'Neill: Early Nō Drama (1959)

o.p.

K. P. K. Whitaker: 1200 Chinese Basic Characters for Students of Cantonese (1953)

K. P. K. Whitaker: Structure Drill in Cantonese (1954)

o.p.

o.p.

Published by Cambridge University Press

D. Cowan: Introduction to Modern Literary Arabic (1958)

Hardbound edition

Paperback edition

*G. Innes: A Mende-English Dictionary (1969)

o.p.

1195

$10 \quad 00$

A. K. S. Lambton: Persian Grammar (1953)

Hardbound edition

Paperback edition

A. K. S. Lambton: Persian Vocabulary (1954)

Hardbound edition

Paperback edition

o.p.

1750

$17 \quad \begin{gathered}\text { o.p. } \\ 50\end{gathered}$

Published by The Manchester University Press

F. G. Bailey: Caste and the Economic Frontier (1957) . . . . o.p.

F. G. Bailey: Tribe, Caste and Nation (1960)

o.p.

Published by Routledge And Kegan Paul, Ltd.

C. C. Brown: Malay Sayings (1951)

o.p.

Published by English Universities Press

P. G. O'Neill: A Programmed Course on Respect Language in Modern Japanese (1966)

Published by MACMILlan AND Co., LTD.

L. W. Hollingsworth: Zanzibar under the Foreign Office 1890-1913 (1953).

[Reprinted by Greenwood Press, Westport, Conn., 1976]

o.p.

Published by STEvens AND Sons, LTD.

A. Gledhill: Fundamental Rights in India (1955) .

o.p.

Published by BRuno CASSIRER, LTD.

D. L. Snellgrove: Four Lamas of Dolpo II (1969) . . . . 1000

Published by G. BeLl AND SONS, LTD.

R. H. Robins: Ancient and Mediaeval Grammatical Theory in Europe (1951)

o.p.

Published by Arthur Probsthain

K. P. K. Whitaker: Cantonese Sentence Series (1954)

Published by TAYlor's ForeIgn Press (Distributed by E. J. Brill)

R. B. Serjeant: Prose and Poetry from Hadramawt (195I) .

o.p. 
WORKS PUBLISHED UNDER THE AUSPICES OF S.O.A.S.

Published by OCEana Publications, InC.

J. de V. Allen, A. J. Stockwell and L. R. Wright (ed.): A

Collection of Treaties and Other Documents affecting the

States of Malaysia, 1761-1963 (1981)

The set of two volumes $\$ 85.00$

Published by Franz Steiner Verlag

P. M. Holt (trans.): The Memoirs of a Syrian Prince: Abu'l-Fidä', Sultan of Hamāh $(672-732 / 1273-1331)$. . . . . Dm. 7200

Published by University Press of America

Russell Jones: Hikayat Sultan Ibrahim ibn Adham (1985)

Published by The Royal Asiatic Society

J. M. Jacob (trans): Reamker (Rāmakerti): the Cambodian Version of the Rāmāyaṇa (1986). $\quad . \quad$. $\quad . \quad . \quad . \quad 17 \quad 50$

Published by The University of Natal Press

D. K. Rycroft and A. B. Ngcobo (ed.): The Praises of Dingana (izibongo zikaDingana) (1988) 


\section{Asian Studies from UNIVERSITY OF HAWAII PRESS}

\section{The Real and Imagined Role of Culture in Society} Case Studies from Indonesia Michael R. Dove, editor

"The importance of the theme and the quality of the writing and presentation should be recommendation enough, for this book raises questions not by any means confined to Indonesia." - Far Eastern Economic Review

304 pages, illustrated, $£ 12.95 \mathrm{pb}$

\section{The Extended Metropolis}

Settlement Transition in Asia Edited by Norton Ginsburg, Bruce Koppel, and T. G. McGee

Asian urbanization is entering a new phase that differs significantly form the patterns of city growth experienced in other developing countries and in the developed world. According to a provocative new hypothesis, zones of intensive activities are emerging. The zones appear to be a new form of socioeconomic organization that is neither rural nor urban, but preserves essential ingredients of each.

The contributors to this volume, seek to determine, from a variety of disciplines, how rapidly, under what circumstances, and on what scale the extended metropolis is emerging.

352 pages, illustrated, $€ 25.00 \mathrm{hb}$

\section{Ilocano Irrigation}

The Corporate Resolution

Henry T. Lewis

Anthropologist Henry T. Lewis' study of the zanjeras, or communal irrigation systems, in Ilocos Norte in the northern Phillippines, focuses on the organizational principles on which they are structured and the related social and environmental factors that have influenced the scale of the development in this particular Ilocano province.

184 pages, illustrated, $€ 19.00 \mathrm{hb}$
Culture and Modernity East-West Philosophic

Perspectives

Eliot Deutsch, editor

A new benchmark for comparative philosophy, this collection of 36 essays will be significant to philosophers of all schools as well as to readers involved and interested in the most current thinking in religion, the theory of science, and sociopolitical problems. Contributors include Karl-Otto Apel, Aziz Al-Azmeh, Margaret Chatterjee, Larry Laudan, Alisdair MacIntyre, Hilary Putnam, Richary Rorty, and Svetozar Stojanovic. 664 pages, $€ 38.00 \mathrm{hb}$

\section{Indonesian Cinema}

\section{Popular Culture on Screen} Karl G. Heider

This anthropological approach to Indonesian film opens up the rich medium of Asian cinema to a new group of scholars. Heider examines the films to indentify pan-Indonesian cultural patterns and to show how these cultural principles shape the movies and, sometimes, how the movies influence the culture.

160 pages, illustrated, $€ 26.50 \mathrm{hb}, £ 6.95 \mathrm{pb}$

Economic Development in the Republic of Korea

A Policy Perspective Edited by Lee-Jay Cho and Yoon Hyung Kim 700 pages, $€ 47.00 \mathrm{hb}$

Korean Administrative Culture

Wanki Paik

220 pages, $£ 23.75$ hb

Academic E

University

Publishers Group

1 Gower Street, London WC1E 6HA

Tel: 0715803994 Fax: 0715803995 


\title{
Princeton \\ Confucianism and Family Rituals in Imperial China
}

\author{
A Social History of Writing about Rites \\ Patricia Buckley Ebrey
}

To explore the historical connections between Confucianism and Chinese society, this book examines the social and cultural processes through which Confucian texts on family rituals were written, circulated, interpreted, and used as guides to action. Weddings, funerals, and ancestral rites were central features of Chinese culture; they gave drama to transitions in people's lives and conveyed conceptions of the hierarchy of society and the interdependency of the living and the dead. Patricia Ebrey's social history of Confucian texts shows much about how Chinese culture was created in a social setting, through the participation of people at all social levels.

Cloth: £19.00 ISBN 0-691-03150-9

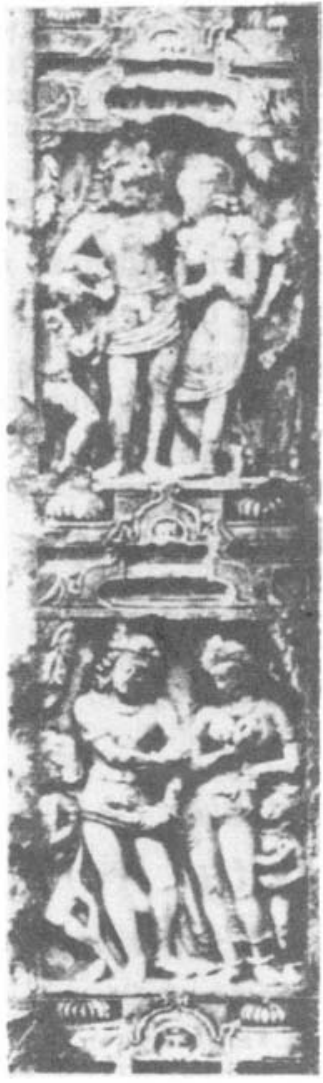

\section{Encyclopaedia of Indian Temple Architecture}

Volume II, Part 2

North India: Period of Early Maturity, c. A.D. $700-900$

\section{Edited by Michael W. Meister} and M. A. Dhaky

This final part of Volume II concludes a wide-ranging study of Nāgara-style temples in North India from A.D. 700 through 900 . The political context and the architectural features of the style are described, along with a detailed analysis of major and lesser-known examples.

"With their wealth of sketches and photographs, these volumes will constitute an indispensable tool for all serious students of Indian architecture and for others seeking comparative information."

-Partha Mitter, University of Sussex

977 black \& white plates.

In two volumes: text and plates

Cloth: $£ 70.00$ ISBN 0-691-04094-X 


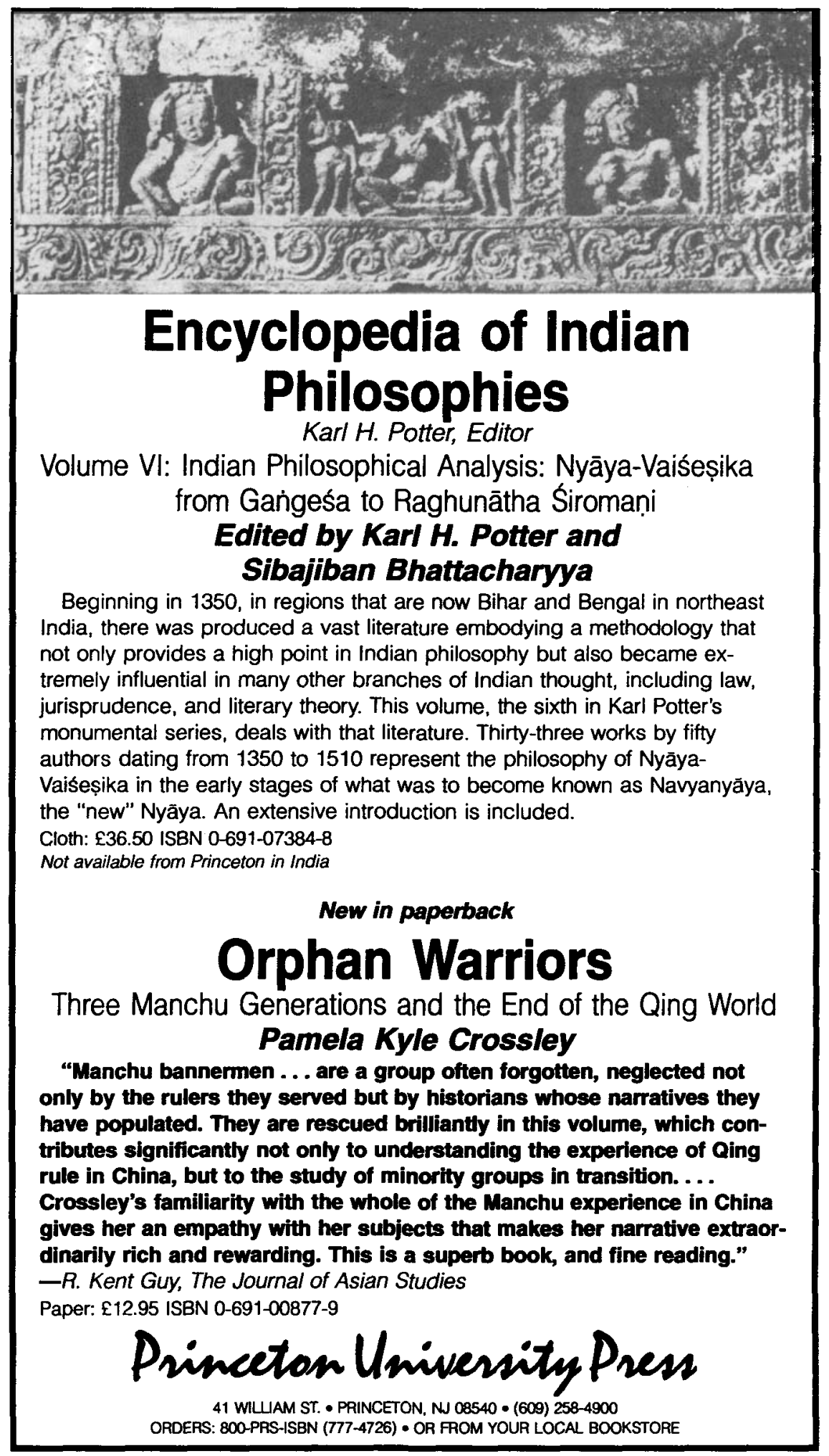




\title{
DEPARTMENT OF CHINESE STUDIES
}

Applications are invited for teaching appointments in the Department of Chinese Studies from candidates who possess a relevant PhD degree. Preference will be given to those who are able to teach in at least two of the following areas:

\author{
Chinese Etymology. Phonology and Semantics \\ Chinese Linguistics, Rhetoric and Grammar \\ Translation \\ Classical/Modern Chinese Literature \\ Modern China/Chinese in Southeast Asia
}

The medium of instruction is Chinese; however, candidates must also be able to teach in English.

Besides appointments on normal 3-year contracts, visiting appointments for one or two years will also be considered.

Gross annual emoluments range as follows:

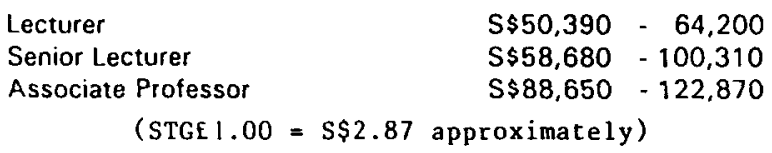

The commencing salary will depend on the candidate's qualifications, experience and the level of appointment offered.

Leave and medical benefits will be provided. Depending on the type of contract offered, other benefits may include: provident fund benefits or an end-of-contract gratuity, a settling-in allowance of $S \$ 1,000$ or $\$ \$ 2,000$, subsidised housing at nominal rentats ranging from $S \$ 100$ to $S \$ 216$ p.m., education allowance for up to three children subject to a maximum of $S \$ 16,000$ per annum per child, passage assistance and baggage allowance for the transportation of personal effects to Singapore. Staff members may undertake consultation work, subject to the approval of the University, and retain consultation fees up to a maximum of $60 \%$ of their gross annual emoluments in a calendar year.

The Department of Chinese Studies is a department in the Faculty of Arts and Social Sciences. There are eight faculties in the National University of Singapore with a current student enrolment of some 15,000. All departments are well-equipped with a wide range of facilities for teaching and research.

All academic staff have access to the following computer and telecommunication resources: an individual microcomputer (an IBM AT-compatible or Apple Macintosh); an (BM mainframe computer with 16 MIPS of computing power; an NEC SX supercomputer with 665 MFLOPS of computing power; departmental laser printers: a wide spectrum of mainframe and microcomputer software; on-line library catalogue; voice-mail; the international computer networks - BITNET and INTERNET, linking academic institutions and research centres all over the world. The campus-wide network, which is based on the high speed optical fibre based FDDI technology, enables the academic community to access the computing resources in the University from the convenience of the individual workstation.

Application forms and further information on terms and conditions of service may be obtained from:

\author{
The Director \\ Personnel Department \\ National University of Singapore \\ 10 Kent Ridge Crescent \\ Singapore 0511
}

\author{
NUS Overseas Office \\ Singapore High Commission \\ (Students Department) \\ 16 Kinnerton Street \\ London SW $1 X$ 8ES, U.K. \\ Tel: (071) 235-4562
}

Enquiries may also be sent through BITNET to: PERLIMSK @ NUS3090, or through Telefax: (65) 7783948 


\section{Publishers and Booksellers \\ $E \cdot J \cdot B R I L L$}

\section{Studies in Hebrew and} Aramaic Syntax

Presented to Professor J. Hoftijzer on the Occasion of his Sixty-fifth Birthday

K. Jongeling, H.L. Murre-van den Berg and

L. van Rompay (eds.)

A collection of essays on syntactical questions in the field of Hebrew and Aramaic, dealing with the nominal sentence, the particle 'et, clause types, word order and concord within sentences, the status and use of particles and verbal forms. 1991. (xvi, 219 pp.)

ISBN 9004095209

Cloth with dustjacket

Gld. 120.00 / US\$ 68.75

\section{Companion Studies to} the History of Tamil

\section{Literature}

\section{Kamil V. Zvelebil}

Addresses problems and topics which have so far been largely ignored, in spite of being of fundamental importance for successful teaching and correct understanding of Tamil literary heritage which spans some 2000 years of development. 1992. (xxvi, 291 pp.)

ISBN 9004093656

Cloth Gld. 168.00/ US\$96.00

\section{Selected Studies}

Presented to the Author by the Department of Indology, Utrecht University

J. Gonda

The present two volumes, arranged in chronological order, deal almost exclusively with Vedism, covering the period 1972 till now. 1991. (ca. 1208 pp.) ISBN 9004094466

Cloth Gld. 550.00/ US $\$ 314.30$

\section{The Monumental}

Inscriptions from Early Islamic Iran and Transoxiana

Sheila S. Blair

This book studies the surviving 79 monumental inscriptions from the Iranian world that date to the first five centuries of the Muslim era (ad 622-1106).

1992. (xvi, 307 pp.)

ISBN 9004093672

Cloth with dustjacket

Gld. 185.00 / US\$ 105.75

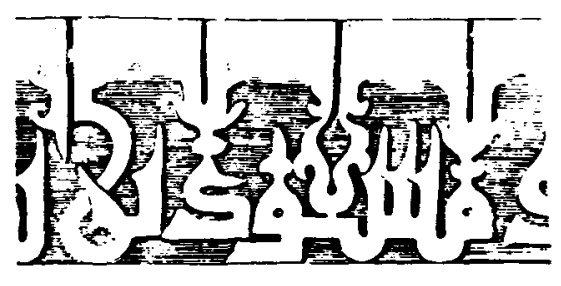

- P.O.B. 9000 - 2300 PA Leiden - The Netherlands /

U.S. and Canadian customers - 24 Hudson Strect $\bullet$ Kinderhook, NY $12106 \bullet$ USA. Call toll-free 1-800-962-4406 (US and Canada only). Prices are subject to change without prior notice and are exclusive of handling costs. USS prices are valid for USA only. 


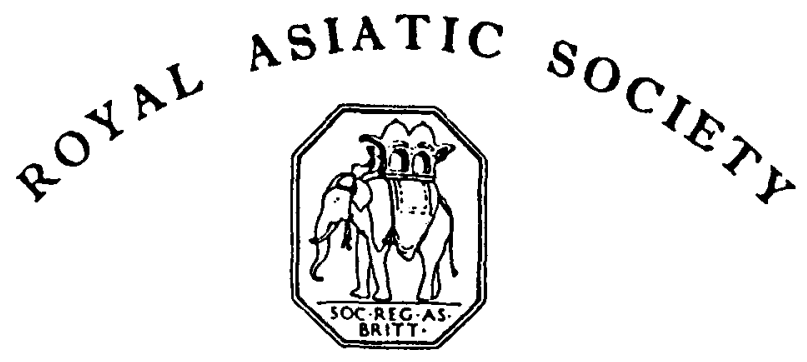

O.W. SAMSON TRAVELling AWARD (1992)

Applications are invited for a recently instituted travelling scholarship in memory of the late Dr O.W. Samson, to enable a graduate student to travel in furtherance of his/her research.

Applicants should have completed their first degree at a British university and be registered or be intending to register for a higher degree in the fields of archacology or anthropology relating to Asia. There is no restriction on age or nationality, but no scholar will be permitted to recieve the award more than once. The value of the award is expected to be in the region of 11000 .

Applications giving full details of the applicant's academic career and research interests, the project for which the grant is sought, and the names of two referees acquainted with the applicant's work, should be submitted to the Secretary, Royal Asiatic Society, 60 Queen's Gardens, London W2 3AF no later than 31st May 1992. The successful applicant will be notified by 1 st July 1992, and will be expected to report to the society on the progress of his/her research within 12 months after the receipt of the award.

\section{WANTED TO PURCHASE}

Back-issues of scholarly periodicals and journals relating to Oriental and African Studies (including: BSOAS)

GRAHAM JEFFREY, PERIODICALS.

Established: 1967

29, Cuddesdon Road, Horspath, Oxford. OX9 1JD

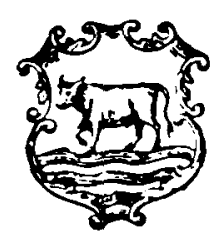

Cable Address: PERIODOX OXFORD

Telephone

WHEATLEY $2 \$ 28$

(STD: 08677 2528) 


\section{Second Level Hausa: GRAMMAR IN ACTION}

\section{GRAHAM FURNISS}

A course book for second-year students of Hausa.

The theme of the year's work is the operation of the verb in

Hausa and the syntax of the simple sentence.

\section{6 pages $£ 8.00$ ISBN 0728601842}

Published by The School of Oriental and African Studies Thornhaugh Street, Russell Square, London WC1H OXG

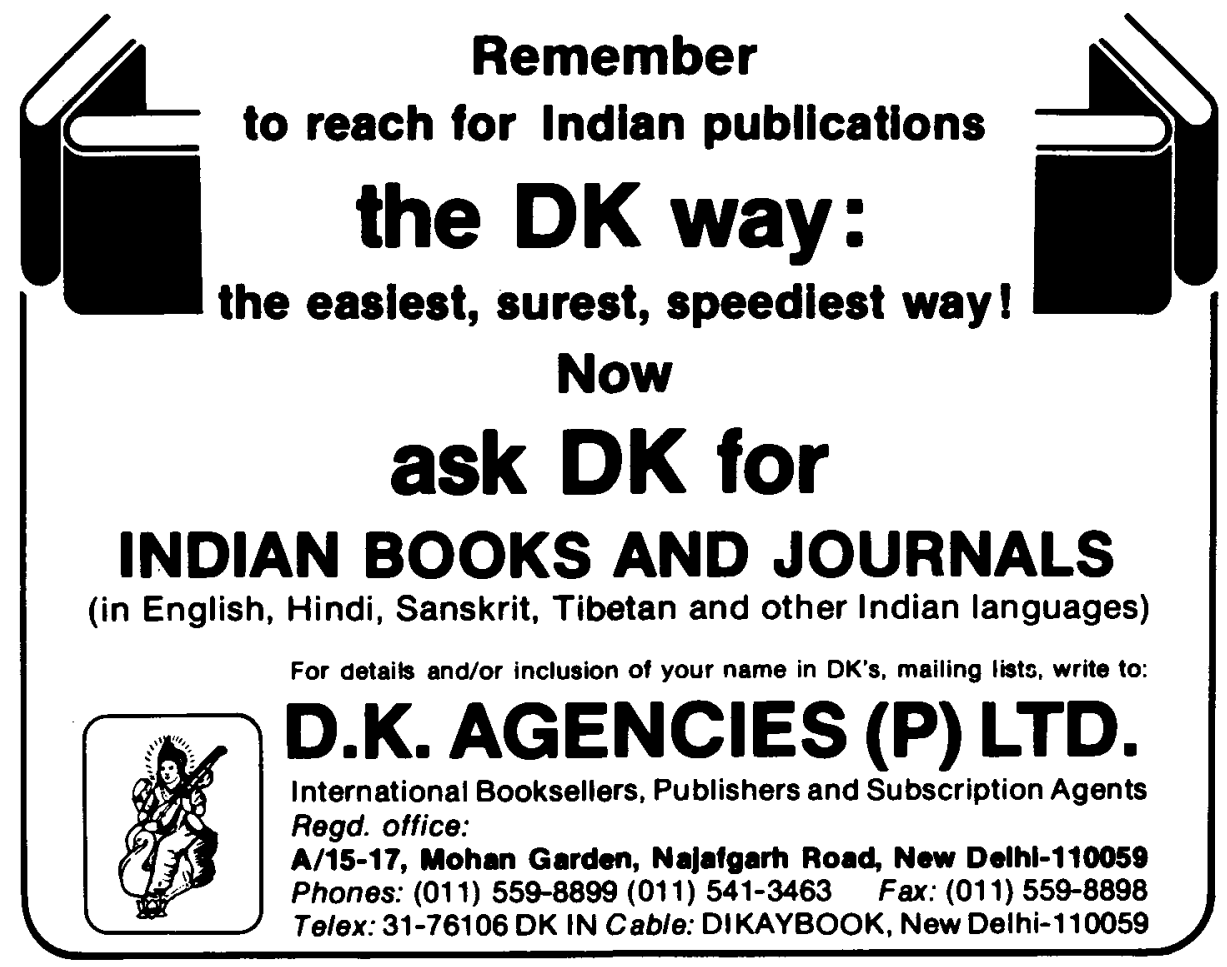


父司

Stephen

子 提 Austin

Caxton Hill Ware Road Hertford Hertford 584955

有 芬 and

限 奥 Sons

公司 Limited

for printing

in all the

world's

司丁

languages 